\title{
Game Localization: Loss and Gain in Visual Novel Subtitles
}

\author{
Etty Syafa'ati
}

English Literature Department, IAIN Surakarta

Email: ettysyafa@gmail.com

Umi Pujiyanti

English Literature Department, IAIN Surakarta

Email: uphaupho@gmail.com

DOI: http://dx.doi.org/10.18326/rgt.v10i2.170-184

\begin{abstract}
Submission
Track:

ENGLISH ABSTRACT

Received:

$13-08-2017$

This research discussed about loss and gain in the context of game

Final Revision: localization with the limitation on subtitles. The objectives are to present the loss and gain in the visual novel game adaptation subtitles

$10-11-2017$

Available online: entitled A Child in the Forest and to identify reasons of the loss and gain happen. A Child in the Forest is a kind of game which consists of static and background images also music soundtrack with storylines and dialogues. It was made and translated from English into Indonesian version by English Letters students of IAIN Surakarta. The method used in this research is descriptive qualitative. The method of collecting data, researcher gets English and Indonesian subtitles script from the game packages. After that, the researcher analyses the data which consist of loss and gain and also make interview with translator. The researcher uses informant to make data validation which is expert in translation and in the world of visual novel game. The result of this research, researcher found 63 data about loss and 55 data about gain. The reasons of loss and gain in visual novel game subtitle is mostly because of the translator wants to reach the goal of game localization in order the visual novel can be easy to be played and to be understood.
\end{abstract}

Keywords: Game Localization, Loss and Gain, Subtitle of Visual Novel Game.

\section{INDONESIAN ABSTRACT}

Penelitian ini membahas tentang loss dan gain dalam konteks game lokalisasi dengan fokus hanya pada subtitle. Tujuan dari penelitian ini adalah untuk menunjukan loss dan gain yang ditemukan serta mengidentifikasi alasan 
kenapa loss dan gain bisa terjadi di subtitle visual novel game adaptasi berjudul A Child in the Forest. A Child in the Forest adalah sebuah permainan yang terdiri dari gambar statis dan latar belakang juga suara music dengan alur cerita dan dialog. Visual novel ini dibuat dan diterjemahkan dari bahasa Inggris ke bahasa Indonesia oleh siswa jurusan sastra inggris semester 2 IAIN Surakarta. Metode yang digunakan dalam penelitian ini adalah penelitian deskriptif kualitatif. Metode pengumpulan data, peneliti mendapatkan naskah terjemahan bahasa Inggris dan bahasa Indonesia dari data paket permainan. Setelah itu, peneliti menganalisis data yang mengandung loss dan gain dan juga melakukan wawancara dengan penerjemah. Peneliti menggunakan informan untuk melakukan validasi data yang ahli dalam dunia penerjemahan dan ahli dalam game visual novel. Hasil penelitian ini, peneliti menemukan 63 data tentang loss dan 55 data tentang gain. Alasan loss dan gain dalam subtitle game visual novel ini sebagian besar karena penerjemah ingin mencapai tujuan lokalisasi permainan agar visual novelnya mudah dimainkan dan dipahami.

Kata kunci: Lokalisasi Game, Loss dan Gain, Subtitle di Visual Novel Game.

\section{INTRODUCTION}

Studies on interlingual subtitles in the context of screen translation revolve around subtitle and subtitling standard differences between film and games (Sajna: 2013), constraints and challenges (Mangiron and Ohagan: 2006), comparative study between TV, DVD, and game (Mangiron: 2013) and also strategies in translating video games in the context of game localization (Costales, 2014). The gap left by those studies is the study of subtitle in the context of video game localization with loss and gain as the perspectives. To reveal the loss and gain in video game subtitles in game localization and to figure out the reasons why this happens are the objectives of this research.

Different characteristics on media and how the media is accessed contribute to the possibilities of loss and gain emergence. In the case of subtitling for example, subtitles appearing on different media, film, for instance, are mechanically different from subtitles on video game screen. Game subtitles are generally longer than subtitles for film. According to Mangiron (2013:44-45), the length of time game subtitles are displayed on screen is variable. Mostly, user controlled in games while in film or TV, time on screen rule is only for 6 seconds. Furthermore, in the parameter of the character per line for film are 35-37 and for game subtitling are 30-143 characters. Mangiron also adds that general subtitling guidelines are not applied in games and it describes the different features such as mentioned above, time variable displayed on the screen, number of lines and also font type, font size and reduction. She adds that reduction in game subtitling must be little for interlingual subtitles as compared with TV subtitling. However, it does not rule out the possibility that another factor might 
REGISTER JOURNAL

Vol. 10, No. 2, 2017, pp.185-199

p-ISSN: $1979-8903$; e-ISSN : 2503-040X

Website: http://journalregister.iainsalatiga.ac.id/index.php/register/

cause loss and gain such as the ability of the translator in understanding the both language and also special skill in understanding the rule and the concept of the game. In fact, because of those reasons, researcher will find whether the loss and gain are caused by the use of different media or there are other reasons applied.

This paper tries to present the loss and gain in the visual novel game adaptation entitled $A$ Child in the Forest. Visual Novel (VN) typically articulates its narrative by means of extensive text conversations complemented by lovingly depicted (and mainly stationary) generic backgrounds and dialogue boxes with character sprites determining the speaker superimposed upon them (Cavallaro, 2009:8). In other words, visual novel is a general type of game with storyline and dialogues. There are also elements such as characters, background images, and sounds.

The VN of A Child in the Forest itself has storylines which are the adaptation from the story entitled A Child in the Grave by Hans Christian Andersen. It made by English Letters students of IAIN Surakarta. They made it from English into Indonesian and that it is used as the object of study for this research which focus only in subtitles. The reasons why researcher chooses $A$ Child in the Forest visual novel game because it is unique visual novel for it is combining pictures of people with animation as the element in the game. It is actually new challenge in the visual novel as usulaly vn employs only animations to be displayed on the screen. Furthermore, the translator and the maker of the visual novel game is students of English Letters in second semester in academic year 2015/2016. At this level of age and in the context of IAIN, producing such kind of work is massive achievement.

Visual novel entitled $A$ Child in the Forest tells about a little girl who lives in the village with her parents. This girl was beautiful, kind and smart. Her father was a carpenter and the mother was a florist in the city. The girl always obeyed her parents. Until one day, she entered the forest without permission of her parents. Then, she was kidnapped by witch who acted as old woman. She regretted and realized her mistakes. One day, a fairy appeared and helped little girl to come back home. The moral value is already familiar or known as children must obey their parents.

In this case, the visual novel game entitled $A$ Child in the Forest ready made in English language as a global product and then the translator worked to localize it in Indonesian language. Furthermore, in making subtitles in this VN, localizer or translator must 
be able to running software of this game which name Livin Maker. Livin Maker is one of engines by IAfterSmile Company to make the visual novel game. It shows that this visual novel game could be a part of localization or GILT practice.

Localization is a part of GILT (Globalization, Internalization, Localization, and Translation). O'Hagan (2005:76) states that "The term GILT has been introduced reflecting the complexity involved in making a product or content global-ready". She added that GILT places language transfer in the wider context of globalization and also in the process there is specific criteria have to deal with electronic content or computer software. Meanwhile Mangiron and O'hagan (2006) added that game localization is combining language translation and software engineering, where translated text strings need to be appropriately placed within the software. That is why the ability of translating and also special skill in running software of the game is required to the translator or localizer. If not, the possibility of loss and gain might happen without consideration.

The definition of loss according to Bassnett (2013) is a situation in which terms or concepts in the SL text do not find their substitutes in the TL text and gain exist for the translator at times to enrich or to clarify the SL as a result of the translation process. In other words, loss is the disappearance of certain features in the TL text which are present in the SL text. Whereas, gain is the emergence of certain feature in the TL text which rendered from SL.

Several reasons arise due to the issues of loss and gain such as the characteristics of media in visual novel game. Another reasons appear such as the ability of translator in understanding the both language including cultural knowledge; the goal of game localization or to make visual novel easy to be played and to be understood; the translator itself that deleted and added certain elements to make it more natural in target language; and the problems that are encountered by translators in understanding the words, messages or meaning. (Melis and Albir, 2001).

Furthermore, the goal of the localized game must be innovative and exciting, and, at the same time, it has to be easy to be played and to be understood. In game localization, the feeling of the original 'gameplay experience' needs to be preserved in the localized version so that all players share the same enjoyment regardless of their language of choice (O'Hagan and Mangiron, 2004). They added that no oddities should be present to disturb the interactive game experience, and this is the reason why game localizers are granted quasi absolute freedom to modify, omit, and even add any elements which they deem necessary to bring the game closer to the players and to convey the original feel of game play. 
REGISTER JOURNAL

Vol. 10, No. 2, 2017, pp.185-199

p-ISSN: $1979-8903$; e-ISSN : 2503-040X

Website: http://journalregister.iainsalatiga.ac.id/index.php/register/

From all the reasons, it can be classified into two types. First, it included of narrative aspects, second it is about mechanical aspects. According to Cavallaro (2009) narrative aspect is about the materials such as characters, structures and events of a potential or virtual story. In other words, it is about the text. From the mechanical aspects, it is about engine and mechanic process. In subtitles, the mechanical aspects are included the dialog box, the use of fonts, the pictures effect and the restriction such as space availability.

\section{RESEARCH METHODOLOGY}

Descriptive qualitative method is applied in this research. Bogdan \& Taylor in Moleong (2014) state that "qualitative method is a research procedure which produces descriptive data in the form of written or oral words from people and their behaviors that are observed". (p. 4). In qualitative research, the data may be in the form of word, phrase, clause or even sentences. In this particular research, the Indonesian and English data script are taken from the visual novel game packages as the sources of data.

Then, the researcher compared the Indonesian subtitles with the original English story to find loss and gain. After the data of loss and gain arecollected, the data are validated by expert to see whether the data are true belong to loss and gain. After that, the researcher classified them based on the linguistics unit.Furthermore, the researcher also used the method of analyzing the content and make interviewing the translator of the game to reveal the reasons why of loss and gain happen.

\section{DISCUSSION}

In this part, researcher shows the results of the research or the data analysis of loss and gain in Indonesian subtitle of visual novel entitled A Child in the Forest. From the results of research, the researcher found 118 data about loss and gain. For the brief explanation, the researcher explains it into the following tables below.

Table 1. Data loss in the subtitles of visual novel A Child in the Forest.

\begin{tabular}{ccc}
\hline No. & Level of Loss & Quantity \\
\hline 1. & Word & 38 \\
2. & Phrase & 17
\end{tabular}




\begin{tabular}{ccc}
3. & Clause & 6 \\
4. & Sentences & 2 \\
\hline & Total & 63 \\
\hline
\end{tabular}

From the table above, it can be seen that 63 data are belong to loss. From the 63 data, it covers 4 form linguistics units, they are: 38 data at the level of words, 17at the level of phrase, 6at the level of clause, 2 at the level of sentences.

Table 2. Data gain in the subtitles of visual novel A Child in the Forest.

\begin{tabular}{ccc} 
No. & Level of Gain & Quantity \\
\hline 1. & Word & 32 \\
2. & Phrase & 23 \\
\hline & Total & 55 \\
\hline
\end{tabular}

From the results, the researcher found 55 data which belong to gain. They cover into 2 form linguistics unit: 32 data at the level of word and 23 at the level of phrases.

\section{Loss at the Level of Word}

Researcher found loss at the level of word. They are not translated or it means loss in the target text. The discussion and reason of loss at the level of word level can be seen through examples below:

\section{Example 1, LW 20}

ST: How many times I told you, the forest is toodangerous for you.

TT: Berapa kali harus Ibu katakan, hutan itu berbahaya untukmu.

From the example 1 above, translator removed the word "too" in the TT. The word "too" in ST confirms that the forest which visited by the little girl is not only dangerous but very dangerous. The emphasis of the word "too" is different with the meaning is just dangerous. The researcher analyzed that if the word "too" is deleted there has been a loss of 
REGISTER JOURNAL

Vol. 10, No. 2, 2017, pp.185-199

p-ISSN: $1979-8903$; e-ISSN : 2503-040X

Website: http://journalregister.iainsalatiga.ac.id/index.php/register/

meaning in TT but it is not such a big deal. The translator also agree with this because if it seen further, the target language and storylines are for children. It is better if the translator make the TT as simple as possible. Thus, the loss of word "too" helped the meaning looked simpler and it helped the reader easy in catch the whole story. If it translated using literal translation strategy it must be "Berapa kali harus ibu katakan, hutan itu sangat berbahaya untukmu".

\section{Example 2, LW}

ST: Because I want to go home. $\underline{I}$ wanna meet my family

TT: karena aku ingin pulang kerumah dan bertemu kedua orangtuaku.

In the example number 2, there is a word "I" in the second sentence of ST that could not be found in TT. Translator did not translate it. The loss at the level of this word is happened because translator said, she wanted to make the meaning as simple as possible. The translator translated two sentences into only one sentences. In this case, the target text already adjusted and it has different structure with the source text. She deleted the word "I" and the word "and" is added. Certainly, in Indonesian language structure when two sentences with the same subject are combined, the repetition of the subject no longer needed. If it repeated the structure of sentences will not neutral in target language. Thus, the adjustment of the structure from English to Indonesian is applied. Furthermore, by combining and changing the structure will make the target text simpler. So that, this has something in line with the goal of game localization which to make visual novel subtitles easy to be read, played and understood.

After analyzed all the data loss, the researcher found the total data about loss at the level of words are 32 data. The mostly reason why loss at the level at words happen because of translator wants to make the target text look simple. It will help the reader to reach the goal of visual novel which to make it easy to be played and to be understood. 


\section{Loss at the Level of Phrase}

Phrase is a group of words acting as a single part of speech and not containing both a subject and a verb. It is a part of sentence and does not express a complete thought. The phrase form contains a broader meaning when compared with the word level, so that if there is a meaning that is loss in this level, the meaning lost in ST will be wider. However, the translator has reasons why loss in this case happen. Here the analysis:

\section{Example 3, LP 2}

ST: There was a happy family in the village.

\section{TT: Kisah itu tentang keluarga bahagia.}

Phrase "in the village" is a prepositional phrase which the meaning explain the place of the family. The writer has a specific purpose by mentioning "in the village". When the phrase is not translated, so not all the meaning of the SL fully conveyed.

The reason of the loss in this phrase, the translator said she confused about the meaning "in the village". This sentence itself is a part of second utterance by the narrator which the first utterance the narrator said "Today, I will read you a story about a child and her family who lived in the border of the forest". The narrator already told that the family lived in the border of the forest and then the next utterance "There was a happy family in the village" is mentioned. The translator thought it has different meaning if "in the village" is translated into di sebuah desa. It will make the readers confused too because of the different information of the place. However, when the phrase "in the village" has been loss, the reader still know the context and understand the full picture of place by the utterance before and also picture of visual novel which supported it. There is not only the phrase of "in the village" which has been lost but the phrase of "There was" also deleted and it changed into kisah. Then, the researcher analyzed that the translator used the strategy of free translation in translating the source text into target text.

\section{Example 4, LP 3}

ST: It's too dangerous, just go back to the house, ok?

TT: disana terlalu berbahaya, sayangku. 
REGISTER JOURNAL

Vol. 10, No. 2, 2017, pp.185-199

p-ISSN: $1979-8903$; e-ISSN : 2503-040X

Website: http://journalregister.iainsalatiga.ac.id/index.php/register/

The meaning of the phrase "just go back to the house" is not conveyed to TT so the meaning of the TT is not entirely equal with ST. In that phrase, the translator translates "just go back to the house" to "sayangku" which means very much different. The context of the story is about a mother who remind a little girl not to go far away from home. The reason why this phrase has been loss is because in the text before her mother already said about the little girl to go home. The translator did not want to repeat it again. Because of those reason, she preferred to reduce it. In addition, the researcher analyzed that the word sayangku is added to emphasize that the prohibition from the mother is not a sign of angry but it is a sign of love to her daughter. From the total of loss at the level of phrase in the subtitle of $A$ Children in the Forest visual novel game, researcher found 17 data.

\section{Loss at the Level of Clause}

In this research, researcher found loss at the level of clause. Here the analysis below:

\section{Example 5, LC 6}

ST: After the witch left her house, she tried to go out from the house, but the door was locked.

TT:setelah si penyihir meninggalkan rumahnya, si anak perempuan itu mencoba untuk melarikan diri.

There is utterance by narrator which explain about the little girl condition after she was kidnapped by the witch. By those full utterance from ST and its subtitle in Indonesian, it can be seen that the last sentences of utterance above "but the door was locked" is not translated in TL. In this case, the loss happened because the translator intentionally deleted just to make visual novel subtitles easy to be understood. Furthermore, the space that available after this sentence is limited. Although visual novel game have wider space compared to TV subtitles but when the dialog box of subtitles is full it will make the translator cannot added another words or clause. In this case, the clause has been loss because the translator abolished it to fit the dialog box of subtitles. The total data of loss at the level of clause is 6 data that could be found by the researcher. 


\section{Loss at the Level of Sentences}

In A Child in the Forest subtitle, there are 2 data loss found at the level of sentence.

\section{Example 6, LS 1}

ST: Please forgive me for everything I have done.

TT: -

\section{Example 7, LS 2}

ST: I did not do what my father and mother said. I'm very sorry about that... And I....

TT: aku tidak mematuhi apa yang kedua orangtuaku katakan dan aku.....

From the example number 6 above, translator did not translate full sentence into target language whereas from the example number 7, the sentence of "I'm very sorry about that" is loss. Loss occurs because of a sentence that is not translated into the TL by the translator. The translator may assume that the non-translated sentence does not affect the plot of the existing story in the visual novel and does not affect the comprehension of the meaning. In fact, the loss of a sentence can make the reader confuse about the storyline.

In this case, those sentences are come from the Little Girl's utterance. The context of the story is to tell about the feeling of little girl which she did not obey the words of her parents, so that she felt very sorry. The utterance of very sorry already spoken by little girl four times before. The researcher analyzed that the reason of this loss at the level of sentence because the translator does not want to repeat the same message repeatedly. Furthermore, the messages of very sorry before already successfully represent the apology messages from the number 6 and 7 which has been loss.

\section{Gain at the level of word}

The researcher found 32 gain data in the subtitle $A$ Child in the Forest visual novel game at the level of words. For further discussion, the researcher explain about the details in the analysis below:

\section{Example 8, GW 13}

ST: Okay, let's go back to the house and prepare the meals for you and your mother ibuти.

TT: baiklah, ayo kembali kerumah dan menyiapkan makanmalam untukmu dan 
REGISTER JOURNAL

Vol. 10, No. 2, 2017, pp.185-199

p-ISSN: 1979-8903; e-ISSN : 2503-040X

Website: http://journalregister.iainsalatiga.ac.id/index.php/register/

From the example above the source text "prepare the meals" it has been translated into target text menyiapkan makan malam. The underlined word is the word that added by the translator although this word cannot be found in the ST. The reason of the gain at the level of word is because of the translator make some adjustment between the pictures of visual novel with the Indonesian subtitle displayed. The picture can be seen in figure 1 below.

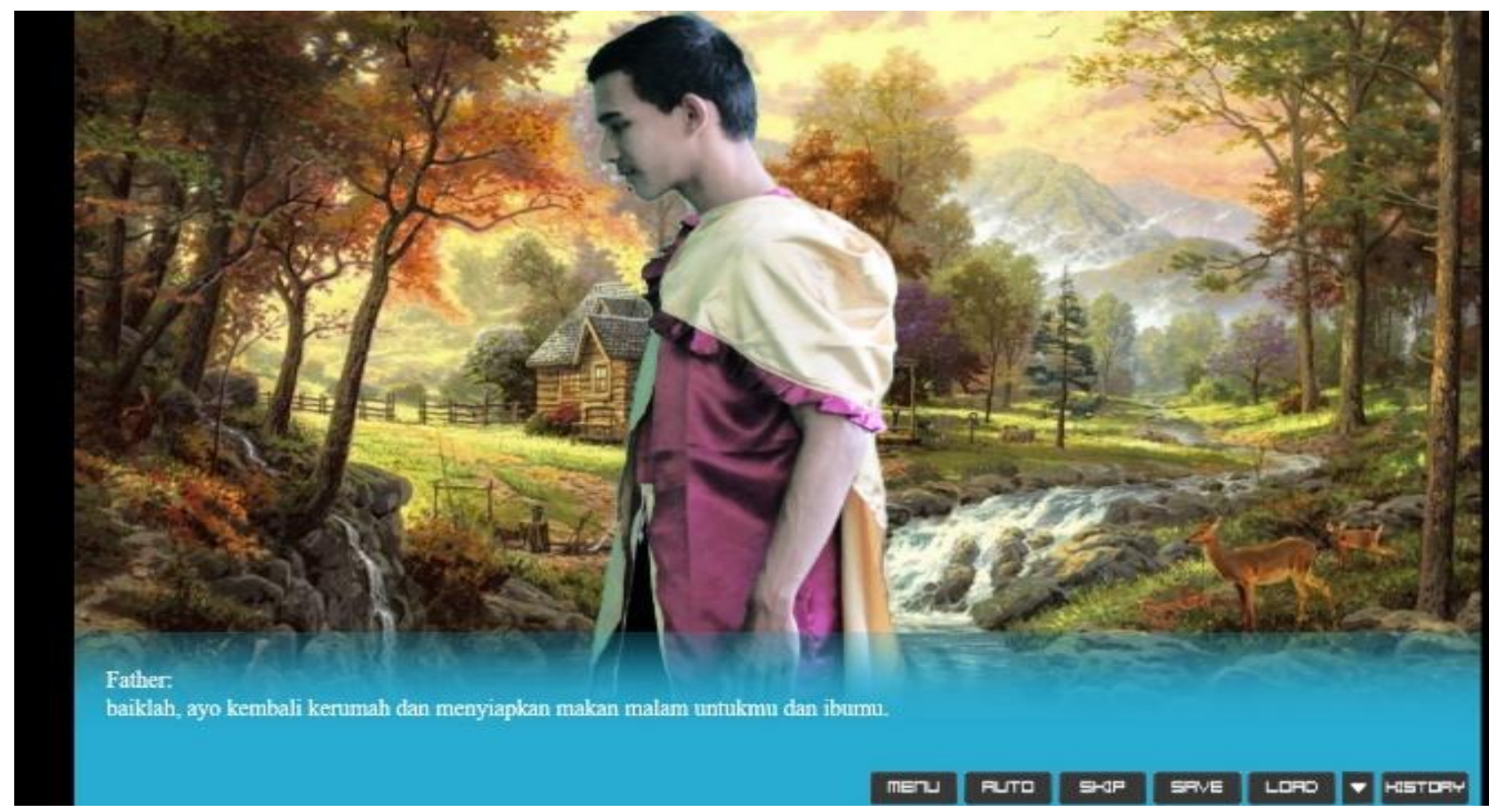

Figure 1

In the figure 1 above, there is afternoon atmosphere depicted. Therefore, the translator intentionally added the word malam in TT to clarify the description of the meal that it was for dinner.

Another example of the gain in the word level can be found in the following example:

\section{Example 9, GW 20}

ST: The old woman brought candy

TT: si wanita tua itu membawa banyak permen. 
In the example number 9 above, the source text said "The old woman brought candy" meanwhile in the target text it is written in subtitles si wanita tua itu membawa banyakpermen. Thus, the translator was gained a wordbanyakin the target language which does not exist in the source language. It has the same reason with the example number 8 . The reasons of the gain word happened is also because the translator wanted to make adjustment of the subtitles with the picture of the visual novel.

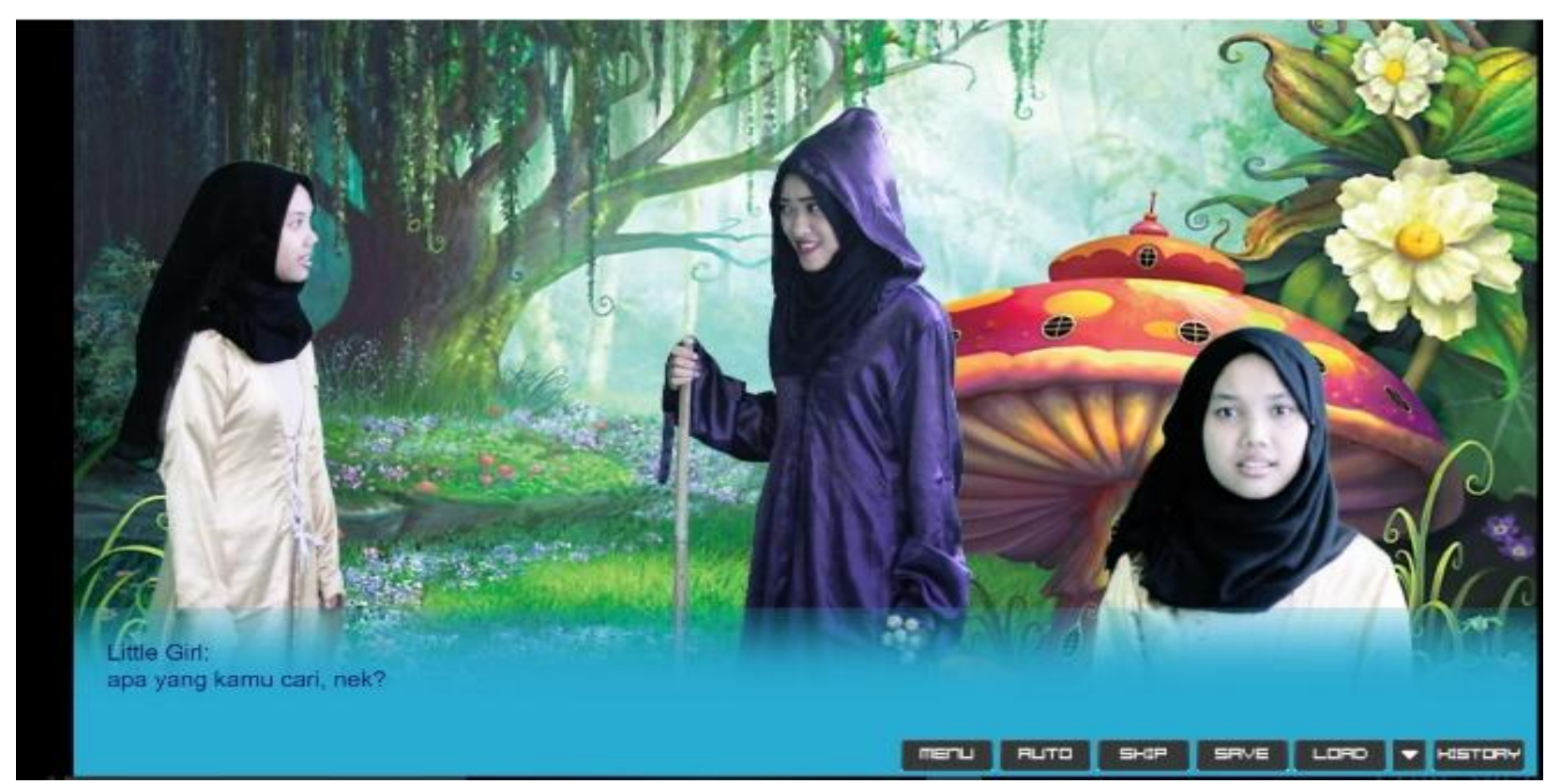

Figure 2

In the figure number 2 , the witch who wear the purples clothes brings many candies. The translator found that the candy in the picture is more than one. Because of that, the translator add the word banyak althought in the ST, the meaning of the "candy" should only one. The researcher concluded that the characteristics of visual novel media and picture in the visual novel caused the gain words occur.

\section{Gain at the level of phrase}

The researcher found 23 data about gain at the level of phrase in the subtitles $A$ Child in the Forest visual novel game. For the further analysis are below:

\section{Example 10, GP 15}

ST: It's okay grandma, let's find the way to go your home.

TT: tidak apa-apa, nenek. ayo aku bantu mencari jalan menuju rumahmu. 
REGISTER JOURNAL

Vol. 10, No. 2, 2017, pp.185-199

p-ISSN: $1979-8903$; e-ISSN : 2503-040X

Website: http://journalregister.iainsalatiga.ac.id/index.php/register/

In the example 10, the little girl says in the source language "It's okay grandma, let's find the way to go your home" meanwhile in the target language it can be read in the subtitle tidak apa-apa, nenek. ayo aku bantu mencari jalan menuju rumahmu. The translator added the phrase of aku bantuin the target language.

The reason about the gain in this case is because the translator intentionally added the phrase aku bantu. This phrase added by the translator just to make the emphasis of the meaning. The researcher also analyzed that it makes the sentences is more natural in the TT and the phrase aku bantu also can be sign of respectful utterance from the younger to the elder.

After analyzed all the data of loss and gain in the subtitles. The researcher classified the reasons of loss and gain are into two aspects namely narrative aspects and mechanical aspects. The reasons which belong to narrative aspects are because it has to do with the text or the story such as the ability of the translator in understanding and translating the messages. Meanwhile, the reasons which belong to the mechanical aspects are something that related to dialog box, the images effects and the restriction of space or limitation.

\section{CONCLUSION}

As mentioned above, this presented paper is about loss and gain found in the subtitle of $A$ Child in the Forest which is transferred intothe same title, A Child in the Forest. There are 118 data of loss and gain found in A Child in the Forest subtitles consisting of 55 data of gain and the 63 data of loss. From the 63 data loss, it covers 4 form linguistics units such as 38 data at the level of words, 17at the level of phrase, 6at the level of clause, 2 at the level of sentences. While in the gain, it covers into 2 form linguistics unit such as 32 data at the level of word and 23 at the level of phrases. In this case, the dominant linguistics units which loss and gain occurred is word.

The reasons why words are dominant in loss and gain because translator sometimes sees a word need to be deleted as it will make the meaning sounds natural in target language. In addition, at 
the level of word in the form of a small case such as pronoun, conjunction, adjective, auxiliary, determiner, adverb, preposition not considered as an important if it eliminated in the target language.

The discussion ends at the conclusion that the most reasons of loss and gain happen is part of mechanical aspects in which translator wants to reach the goal of game localization and the translator wanted to make the meaning simple so it fixed to the dialog box. So that, it will easy to be played and to be understood. Mechanical aspects are caused loss and gain because it deals with to dialog box, the images effects and the restriction of space or limitation.

There are some suggestions that could be drawn from the discussion above. First, for the translators that they have to be more careful in making subtitles for visual novel games. In some cases, it was found that loss also causes subtitles text looks confusing because there are missing parts, so that the message delivered is less clear. At the same time, translator should make the audience understand of the full meaning in the ST story without add the excessively long and trivial subtitles. The researcher also suggests for the further research to make standardization of subtitling for visual novel game. In order to guide the future translator, subtitler of visual novel game.

\section{REFERENCES}

Bassnett, S. (2013). Translation studies. Routledge.

Bell, R. T. (1991). Translation and translating: Theory and practice. Taylor \& Francis.

Bushouse, E. (2015). The Practice and Evolution of Video Game Translation: Expanding the Definition of Translation.

Catford, J. C. (1965). A linguistic theory of translation (Vol. 31). London: Oxford University Press.

Cavallaro, D. (2009). Anime and the visual novel: narrative structure, design and play at the crossroads of animation and computer games. McFarland.

Celso Jr, T. A., Bal-ut, M. L. C., Calam, L. G., Cantuba, R. N., Vallo, M. H. M., \& Apsay, M. R. (2013). Game Development of Ibong Adarna Visual Novel. Fatima University Research Journal, 5(1), 1-1.

Cintas, J. D. (2003). Audiovisual translation in the third millennium. Translation today: Trends and perspectives, 192-204.

Fernández Costales, A. (2012). Exploring translation strategies in video game localization. 
REGISTER JOURNAL

Vol. 10, No. 2, 2017, pp.185-199

p-ISSN: 1979-8903; e-ISSN : 2503-040X

Website: http://journalregister.iainsalatiga.ac.id/index.php/register/

Hsieh, H. F., \& Shannon, S. E. (2005). Three approaches to qualitative content analysis. Qualitative health research, 15(9), 1277-1288.

Kumar, R. (1999). Research Methodology: A step-by-step approach. London: Sage Publications.

Mangiron, C. (2013). Subtitling in game localization: a descriptive study. Perspectives, 21(1), 42-56.

Mangiron, C., \& O’Hagan, M. (2006). Game Localization: unleashing imagination with 'restricted'translation. The Journal of Specialised Translation, 6(2006), 10-21.

Moleong, Lexy J. (2004). Metodologi Penelitian Kualitatif. Bandung: Remadja Karya.

O'Hagan, M. (2005). Multidimensional translation: A game plan for audiovisual translation in the age of GILT. Challenges of Multidimensional Translation, 76-87.

Pettit, Z. (2004). The audio-visual text: Subtitling and dubbing different genres. Meta: Journal des traducteursMeta:/Translators' Journal, 49(1), 25-38.

Sajna, M. A. T. E. U. S. Z. (2013). Translation of video games and films-a comparative analysis of selected technical problems. Homo Ludens 1 (5)/2013, 219-232.

Stemler, S. (2001). An overview of content analysis. Practical assessment, research \& evaluation, 7(17), 137-146.

Syalies, F. N. (2016). A Loss And Gain In Equivalence Analysis Of Noun Phrases In Strawberry Shortcake Bilingual Series Dandanan Kacau Makeover Madness. 